\title{
The Intelligibility of Extralegal State Action: A General Lesson for Debates on Public Emergencies and Legality
}

François Tanguay-Renaud

Osgoode Hall Law School of York University, ftanguay-renaud@osgoode.yorku.ca

Source Publication:

Legal Theory

Follow this and additional works at: https://digitalcommons.osgoode.yorku.ca/scholarly_works

Part of the Ethics and Political Philosophy Commons, International Law Commons, Jurisprudence Commons, Legal Theory Commons, National Security Law Commons, Public Affairs, Public Policy and Public Administration Commons, and the Public Law and Legal Theory Commons (c) (1) $(9)$

This work is licensed under a Creative Commons Attribution-Noncommercial-No Derivative Works 4.0 License.

\section{Recommended Citation}

Tanguay-Renaud, François. "The Intelligibility of Extralegal State Action: A General Lesson for Debates on Public Emergencies and Legality." Legal Theory 16 (2010): 161-189.

This Article is brought to you for free and open access by the Faculty Scholarship at Osgoode Digital Commons. It has been accepted for inclusion in Articles \& Book Chapters by an authorized administrator of Osgoode Digital Commons. 


\title{
THE INTELLIGIBILITY OF EXTRALEGAL STATE ACTION:
}

\section{A General Lesson for Debates on Public Emergencies and Legality}

\author{
François Tanguay-Renaud* \\ Osgoode Hall Law School, York University
}

Some legal theorists deny that states can conceivably act extralegally in the sense of acting contrary to domestic law. This position finds its most robust articulation in the writings of Hans Kelsen and has more recently been taken up by David Dyzenhaus in the context of his work on emergencies and legality. This paper seeks to demystify their arguments and ultimately contend that we can intelligibly speak of the state as a legal wrongdoer or a legally unauthorized actor.

General theorizing about state responses to public emergencies-or, to speak in the terms of art, theorizing about "emergency powers" or "states of emergency"-is often deemed worthless. Skeptics ask: Is it not the case that, given the elasticity of the concept of emergency and the wide range of events that may qualify as such, general attempts at theorizing state responses to them are no different from attempts at theorizing state responses to, say, events that happen on Wednesdays? There seems to be at least some truth to this objection. Then again, public emergencies continue to fascinate contemporary legal and political theorists, a fact that leaves one to wonder whether there may not be more fundamental and interesting issues at the root of their unrelenting interest. The central goal of this article is to unearth and address one such issue, whose importance transcends the province of emergencies: Does it make sense to think of states as entities capable of acting in ways that depart from the law?

Carl Schmitt, whose work often constitutes the starting point of treatises on emergencies and legality, thought the answer obvious. For him, "it is

\footnotetext{
*I would like to thank Elizabeth Angell, John Gardner, Michael Giudice, Leslie Green, Wil Waluchow, the participants in the Oxford Jurisprudence Discussion Group, at which this paper was presented in May 2010, as well as two anonymous referees, for discussion, comments, and criticisms. Special thanks are also owed to David Dyzenhaus for sharing some of his work prior to publication.
} 
clear that," in various exceptional situations, "the state remains, whereas law recedes." "However, this position is contentious and sometimes rejected on the ground of unintelligibility. This kind of challenge has most recently been associated with the work of David Dyzenhaus, who argues that "when a political entity acts outside of the law, its acts can no longer be attributed to the state," and moreover, "they have no authority."2 It is with this conceptual rejoinder and its most salient lineage-namely, the work of Hans Kelsenthat I take issue in this article. I argue that whereas the correct position may not be as obvious as Schmitt thought it to be, states can intelligibly depart from domestic law ${ }^{3}$ and contravene both its duty-imposing and its authorizing norms. This conceptual possibility is important, since it allows us to ask intelligibly when, if ever, states may or should depart from the law and what kinds of ex ante and ex post controls and modes of accountability should be in place to deal with extralegal state actions. Conflations of state and law à la Dyzenhaus and Kelsen should not stand in the way of such important inquiries.

\section{TWO SETS OF PRELIMINARY CONSIDERATIONS}

\section{A. Situating the Inquiry: Avoiding Dyzenhaus's Normative Red Herrings}

When thinking about the question that is being asked here in light of recent scholarship on public emergencies, one must be careful not to misunderstand it and slip into a more normative or moral kind of inquiry. The question I am asking is this: Does it make conceptual sense to think of states as having the ability to act extralegally? For Dyzenhaus, who claims to be following Kelsen's views on this issue, the answer is negative. However, unlike Kelsen's position, to which I return in greater detail in Section II, Dyzenhaus's position also has a moral dimension, which tends to obscure this conceptual commitment. ${ }^{4}$ Exploring briefly how it does so allows me to situate my inquiry in relation to different yet related questions that could

1. C. Schmitt, Political Theology: Four Chapters on the Concept of Sovereignty (G. Schwab trans., 2005), at 12.

2. D. Dyzenhaus, The Constitution of Law: Legality in a Time of Emergency (2006), at 199. He sometimes provocatively refers to this thesis as "the central assumption of legal theory." D. Dyzenhaus, The Compulsion of Legality, in EMERGENCIES AND THE Limits OF Legality (V.V. Ramraj ed., 2008), at 36, 56-57.

3. In this article, I bracket, by and large, questions about international law.

4. To be more precise, while Dyzenhaus often claims to adhere to Kelsen's conceptual framework, recent writings betray the fact that he also construes it through the prism of political morality. For example, in an essay to be published in French as L'état d'exception, in TraITÉ INTERNATIONAL DE DROIT CONSTITUTIONNEL (M. Troper \& D. Chagnollaud eds., forthcoming 2010), he explicitly writes that Kelsen's position can also be understood "not with Kelsen himself as the expression of a scientific hypothesis about the nature of law, but rather ... as liberalism's political aspiration to have all public power controlled by law" (page 7 of English typescript, on file with the author). 
also be asked about the relationship between state and law-questions that can be conflated with the conceptual question I am asking only on the basis of questionable assumptions.

For Dyzenhaus, the argument is "not only that the state's authority has to be exercised through law, but also that this requirement provides a moral basis for the state's claim to authority" wherever and whenever it may manifest itself, including in times of severe public emergencies. ${ }^{5}$ Admittedly, it is widely believed that there is special virtue in regulating conduct by law because of certain important values that legal systems help secure. As a result, adherence to the rule of law is often considered to be one of the central determinants of the moral legitimacy of state governance. The rule of law, it is often claimed, is preferable to arbitrary government or anarchy. However, even if one concedes arguendo that the rule of law is preferable to other forms of rule (and nonrule) and that states should seek to abide by it, this concession does not entail that states cannot conceivably depart from the law.

Much of the tension in Dyzenhaus's work emanates from his endorsement of a thick conception of law and of the value of its rule, one that "links procedural constraints to substantive values. ${ }^{6}$ Dyzenhaus understands the rule of law as an aspiration that should be shared by all branches of government to secure values, such as "fairness, reasonableness, and equality," whose content "is inevitably influenced by our evolving view of the individual who is subject to the law ... as a bearer of human rights." "His conception is so thick that it leads him to describe law as a potentially "inexhaustible" repository of "moral resources" for the states it regulates. ${ }^{8} \mathrm{He}$ goes on to query whether "law" that did not contain such resources would still really be law, since "law presupposes the rule of law, in the substantive sense."

For Dyzenhaus, then, the rule of law amounts to something like the rule of fundamental values and, for all intents and purposes, it is coterminous with morality in its application to states. ${ }^{10}$ Since morality is not the type of thing that those to whom it applies can avoid, it is not surprising that he claims that states should always act "within the law" and "through law," that is to say, morally, even when confronted with severe emergencies. Note, however, that even if one accepts Dyzenhaus's thick conception of legality, this last observation in no way entails that states cannot, conceptually speaking, act illegally (qua immorally), or even, as he also claims, that it is always possible

5. Dyzenhaus, Compulsion of Legality, supra note 2, at 37.

6. Dyzenhaus, Constitution of LaW, supra note 2, at 14.

7. Id. at 13 .

8. Id. at 63-65.

9. Id. at 4-7. Law, as he later reformulates, "is constituted by values that make government under the rule of law worth having," $i d$. at 139.

10. He sometimes speaks of "constitutional morality." See, e.g., D. Dyzenhaus, The Puzzle of Martial Law, 59 U. ToronTo L.J. 1-64 (2009), at 39, 49, 53. 
for them to act in legally (qua morally) acceptable ways. ${ }^{11}$ For example, there may well be situations, often referred to as moral dilemmas, in which all options available to a state would involve unjustified moral wrongdoing. Although Dyzenhaus is probably right to point out that no theory of morality or legality should focus exclusively or even centrally on such tragic cases, they can certainly not be ignored.

Oddly, Dyzenhaus resolutely refuses to concede this point, given his adherence to what he takes to be Kelsen's core conceptual commitment-that is, that the notion of state presupposes the notion of law and that a state is in fact nothing but a national legal system. ${ }^{12}$ To the extent that this "identity thesis" is accurate, it is indeed difficult to claim intelligibly that a state can depart from the law of that system-that is, from itself. I return later to Kelsen's thesis. For the moment, notice only the implausibility of coupling such identification of state and law with the claim that law is akin to public morality. This juxtaposition of claims implies that states cannot act immorally, which no doubt represents a deeply counterintuitive proposition. If Dyzenhaus held the common view that law is irredeemably morally fallible, this problem would not arise, but remember that his claim is that law's potential to provide appropriate moral resources is inexhaustible.

To be fair, Dyzenhaus does, in a somewhat curious way, recognize that law-let us refer to it as morally legitimate law to account for his view-can sometimes run out. He persistently refuses to distance himself from A.V. Dicey, who maintains that the prospect of "times of tumult or invasion" requiring illegal state responses can never be fully discounted. ${ }^{13}$ I say that this admission is curious, since Dyzenhaus, to avoid falling prey to a paradox, is forced to drive an uneasy wedge between "law" and "legality," or between what he also calls "rule by law" and "rule of law." According to this distinction, state reactions to public emergencies may intelligibly fall foul of the law yet be "legal" at the same time. Unlawful reactions are legal in this sense-Dyzenhaus speaks of reactions in a "spirit of legality"-when they constitute proportionate responses that uphold what he counts as legal values. This move, he thinks, enables him to reconcile his own claim about the unintelligibility of state illegality with Dicey's remarks about the possible need for official illegality in times of emergency as well as about the appropriateness of acts of indemnity that may be adopted ex post facto

11. With respect to this last point, Dyzenhaus claims that to the extent that a state's constitution is sufficiently flexible, it is "possible to exercise power through law in a way that sustains the aspirations of legality." Dyzenhaus, Compulsion of Legality, supra note 2, at 58; D. Dyzenhaus, States of Emergency, in A Companion to Contemporary Political Philosophy (R.E. Goodin, P. Pettit, \& T. Pogge eds., 2007), at 809-810.

12. H. Kelsen, General Theory of Law and State (2006), at 181-192; H. Kelsen, Pure THEORY OF LAW (1967), at 286-319.

13. See, e.g., A.V. Dicey, An Introduction to the Law of the Constitution (10th ed. 1959), at 412-413. Dyzenhaus embraces this part of Dicey's position most clearly in Dyzenhaus, Compulsion of Legality, supra note 2, at 46-48, 54-55, but also discusses it in DyzENHAUs, CONSTITUTION OF LAW, supra note 2, at 53-57. 
to "legalize illegality." He argues that such acts are appropriate when they authorize retrospectively what was already "legal" in some sense. They ought "to secure the rule of law, not to undermine it," to "indemnif[y] action that could and should have been authorized in advance." 14

I say that the wedge Dyzenhaus drives between "law" and "legality" is uneasy for two main reasons. First, by hinting that state agents can sometimes act outside the law yet continue to sustain the aspirations of legality, Dyzenhaus seems to imply that his commitment to the Kelsenian thesis about the identity of state and law is not as firm as he suggests elsewhere. This ambiguity provides evidence that the normative aspect of his argument, instead of bolstering his basic conceptual stance, significantly obscures it. What is more, the arc of his normative argument is itself difficult to comprehend. Recall that despite driving a wedge between law and legality, Dyzenhaus also defends the view that law presupposes the rule of law in a substantive sense. Thus, to be consistent, he is left to defend the converse, seemingly paradoxical view that the rule of law does not presuppose law. Were Dyzenhaus to conceive of the rule of law as a leaner, more legalistic ideal, this point might have merit to the extent that at any given moment, there may be aspects of the life of a society that do not need to be governed by ex ante, clear, general, open, consistent, and stable rules of law for that society to be ruled by law. In fact, excessive insistence on ex ante legal regulation might even turn what would otherwise be a virtue (i.e., legality) into a vice (i.e., legalism). However, under Dyzenhaus's thick conception, the point loses much of the force it might otherwise have had.

To be sure, Dyzenhaus claims that his approach shows that "the exception [qua extralegal state action] can be banished from the legal order." 15 However, this is no more than a pyrrhic victory since it is won by disregarding much of what is distinctive about the rule of law. Moreover, as I remark above, given his thick understanding of legality, Dyzenhaus's amalgam of claims lead us, for all intents and purposes, to the implausibly strong conclusion that states can only and always act in morally acceptable ways.

Ironically, Dyzenhaus thinks that another point in favor of his approach is that it rests on an account of legality that is "more legal" than other, thinner accounts that, he laments, ultimately amount to judicial or popular rule. Drawing heavily on the work of Ronald Dworkin, Dyzenhaus claims that what holds a legal system together is not so much judges or "the people" but values inherent in the law. ${ }^{16}$ Of course, I cannot do justice to all the arguments that have been offered over the years for and against this controversial claim.

14. Dyzenhaus, Compulsion of Legality, supra note 2, at 47. Arguably, it is also this wedge between law and legality that allows him to conceive of wicked systems of law; e.g., D. DyzENhaus, Hard Cases in Wicked Legal Systems: South African LaW in the Perspective of Legal Philosophy (1991).

15. Dyzenhaus, Constitution of Law, supra note 2, at 53.

16. D. Dyzenhaus, The State of Emergency in Legal Theory, in GLOBAL ANTI-TERRORISM LAW AND Policy (V.V. Ramraj, M. Hor, \& K. Roach eds., 2005), at 74-77; id. at 5-7. 
However, even Dworkin would object to a claim that law and legality can pull in completely opposite directions and ultimately come apart in the way envisaged by Dyzenhaus. In the context of his well-known discussion of Mrs. Sorenson's claim for damages, according to market shares, for injuries suffered after taking a generic drug manufactured and marketed by many undifferentiated companies, Dworkin writes: " $[\mathrm{I}] \mathrm{t}$ would be nonsense to suppose that though the law, properly understood, grants her a right to recovery, the value of legality argues against it. Or that though the law, properly understood, denies her a right to recovery, legality would nevertheless be served by making the companies pay." ${ }^{\prime 7}$ Plainly, it is hard to understand what is so legal about Dyzenhaus's thickly value-laden account of legality.

My hope is that this partial yet critical survey of Dyzenhaus's account of the relation between state and law will serve as a note of caution against conflating conceptual and morally oriented normative inquiries too easily, given the important distinctions that tend to be lost or made implausible as a result. In order to focus productively on the very real challenge posed by the identity thesis and avoid Dyzenhaus-like slippages, it is methodologically important to distinguish the conceptual question of whether a state can possibly depart from the law from the issue of the morality of its actions-including the question of whether extralegal public actions infringing the ideal of the rule of law may ever be morally legitimate. It also seems important to default to an understanding of law and legality that makes this distinction at least intelligible. Kelsen, on whose conceptual views Dyzenhaus claims to rest his challenge, embraced these premises. Therefore it is on his more sharply focused conceptual objections that I focus in Section II.

\section{B. Different Types of Illegalities: The Power-Conferring/ Duty-Imposing Rule Distinction}

Another structural issue, neglected by Kelsen and only inconsistently acknowledged by Dyzenhaus, must also be tackled at this preliminary stage if one is to appreciate the multiple facets of their conceptual challenge: state illegality, insofar as it is intelligible, may take different forms. Consider the ambiguity that often surrounds the use of terms like "justification" and "illegality" in the context of the legal regulation of state conduct. State action may be said to be "without legal justification" or "illegal" when it exceeds the boundaries the law sets for the valid exercise of state power. It is also sometimes said to constitute an "unjustified" breach of a legal duty and to be "illegal" as a result. The ambiguity lies in the fact that in both cases the relevant state behavior is legally the "wrong" thing to do, in the sense that it breaches a legal rule whose primary function is to guide conduct. However,

17. R. Dworkin, Hart's Postscript and the Character of Political Philosophy, 24 OXFORD J. LEGAL STUD. 1-37 (2004) at 25. 
as H.L.A. Hart emphasizes, the type of rule at stake is different in the two cases. $^{18}$

In the latter case, it is a duty-imposing (or obligation-imposing) rule that is contravened. Rules of this kind require their addressees to take or abstain from certain actions, whether they wish to do so or not, and are paradigmatic of legal fields such as criminal law and tort law. Breaches of duties imposed by the law are generally conceived as wrongs that as far as reasonably possible should be set right: in the case of tortious and other civil wrongs, by restitution to or compensation of any wrongfully aggrieved party, and in the case of criminal wrongs, barring complete justification, excuse, or other applicable grounds of exoneration, by condemnation and punishment.

However, the rule breached in the first case is of a different sort. It is a power-conferring (or authority-conferring or authorizing) rule. Although such rules also serve to guide behavior, they are best understood not as imposing duties but as conferring normative powers-that is, powers to bring about various changes in their addressees' own normative position or that of others. For example, power-conferring rules may provide that by doing or saying certain things, their addressees may introduce new dutyimposing rules, extinguish or modify old ones, or determine their incidence or control their operations. In Hart's words, power-conferring rules "are more like instructions how to bring about certain results than mandatory impositions of duty." ${ }^{19}$ Legal power-conferring rules supply criteria for the assessment of the legal validity of normative changes, so their breach does not amount so much to wrongdoing as to a legally invalid or ultra vires action. Such rules lie at the core of public law, understood as the amalgam of legal branches such as constitutional and administrative law that specifically seek to regulate the structure and powers of states.

Thus the paradigmatic judicial remedies in public law are not primarily aimed at repairing or requiting but at controlling the legal validity of public action; for example, mandatory or prohibitory orders enjoining a state organ to act within the law, "quashing" of invalid legal changes, or declarations of legal rights and powers, rather than restitution, compensation, or punishment. I invite the reader to keep this distinction in mind in the following sections, even when, as a reflection of the ambiguities of some of the works discussed, I do not draw it as sharply as I do here.

Of course, in the law, duty-imposing and power-conferring rules are often intimately associated. For example, in a common-law jurisdiction such as England, if a state planning commission arranges for work to take place on privately owned land without having the power to do so, it may commit a tort of trespass. A statutory authorization for the conduct of such work

18. See H.L.A. Hart, The Concept of LaW (2nd ed. 1994), chs 3-5; and see further J. Raz, Practical REASON AND Norms (2nd ed. 1990), at 73-84, 97-106.

19. H.L.A. Hart, Essays on Bentham: Jurisprudence and Political Theory (1982), at 219. 
may well immunize the commission against liability by altering its normative position, but in the absence of this immunity, the commission's actions are likely to constitute a civil wrong. A similar analysis may also apply to the case of an American police officer who forcefully arrests somebody whom she does not have the legal power to arrest, and is thereafter charged with battery or assault. ${ }^{20}$ Note further that the exercise of state powers is itself often subject to legal duties. Consider, for example, the various duties of procedural fairness (or natural justice) that are generally held to apply to state agencies with adjudicative powers. Thus legal powers may affect legal duties, and legal duties may constrain exercises of legal powers. However, these frequent interconnections should not obscure the fact that the types of legal rules at stake differ and can be understood separately. When a state agency in charge of issuing licenses for the sale of alcohol issues an invalid one, it may well commit no wrong in the process. The operative rule is power-conferring.

Thus state illegality, insofar as it is conceivable, might result from the wrongful breach of constitutional, administrative, tort, or perhaps even criminal law duties. However, much of public law is concerned with another genre of regulation-power-conferring regulation-that has its own distinct normative functions and consequences. When assessing whether states can intelligibly depart from the law, it will be important to keep in mind both possible types of departures.

\section{STATES AS EXTRALEGAL ACTORS?}

\section{A. Situating and Problematizing Kelsen's Identity Thesis}

With these two sets of background considerations in mind, we are in a good position to inquire into whether states can intelligibly depart from the law. The first thing to note is that Kelsen's conceptual identification of state and law, which is at the root of the puzzle under consideration, has been the subject of much controversy over the years. To start with, it has some odd consequences. For example, it entails that each state can have only one valid legal system and that a colony can never obtain its independence from its colonizer by peaceful legal means (since, for Kelsen, legal continuity implies continuity of state). What is more, the controversy extends deep into debates about the nature and normativity of law, since, when asserting that the state is simply another name for the legal order, Kelsen is really

20. Different legal systems may take different views as to whether legally invalid arrests are also legally impermissible violations of legal duties or, conversely, whether legally impermissible arrests are also legally invalid. Unlike what some criminal law theorists seem to assume, legal permissions to infringe duties and legal powers to act do not necessarily come together harmoniously, even if, as I assume in the text, they sometimes may. Compare: M. Thorburn, Justifications, Powers, and Authority, 117 Yale L.J. 1070 (2008). On the distinction between permissive and power-conferring norms: RAZ, supra note 18, at 85-106. 
contending that a legal system is irreducibly normative and cannot be seen as the product of social facts. Thus he rejects the position, espoused by many other legal positivists, that a sociologically understood entity or practicesay, an independent political society in a habit of obedience to a sovereign, in John Austin's terms, or the social practice of a rule of recognition, in Hart's terms - stands at the foundation of a legal system. For Kelsen, the state is the law and, as such, it is nothing but a "juristic" phenomenon all the way down, tied together by chains of legal validity leading back to a postulated basic norm. As a result, the acts of so-called state organs can genuinely be imputed to the state only insofar as they are "an execution of the legal order."21

Can extralegal action be that of a state, so understood? In a way, it all depends on what is meant by "extralegal." When a government, qua agent of the state, creates new laws by recognizing nonlegal dependent reasons-say, social customs-there is a sense in which it is necessarily acting extralegally since it is bringing external norms into the law. So long as this process of law creation is in tune with the requirements of the legal system, it is compatible with Kelsen's account. What Kelsen denies is that the state can act extralegally in the sense of acting contrary to law. States cannot act in dereliction of duty-imposing legal norms, since that would be antithetical to their very nature; as Kelsen says: "A wrong-doing state would be a contradiction in itself." ${ }^{22}$ Similarly, state organs can never intelligibly be said to exceed the powers conferred upon them by authorizing legal norms. ${ }^{23}$ For Kelsen, there is no need to extend the inquiry any further, since "there is only a juristic conception of the State," and no other. ${ }^{24}$

The inflexibility of Kelsen's position is rather troubling. Besides the grounds for skepticism listed above, one may question how, in light of his conceptual framework, we should interpret civil and criminal law prohibitions targeted at "public bodies" or "the state," 25 or the oft-encountered requirement of "state action" for violations of constitutional law. Kelsen is not oblivious to these features of legal systems. However, his attempts at dealing with them in accordance with his framework are rather tortuous. For example, he posits that legislation or legal regulation that is

21. H. Kelsen, General Theory, supra note 12, at 189, 192.

22. H. Kelsen, Pure Theory, supra note 12 at 305.

23. Kelsen imprecisely treats authorizing or power-conferring norms as fragments of larger duty-imposing norms. That said, he is still able to distinguish between cases in which a governmental agent fails to satisfy such a fragment (and so fails to create any duty-imposing norms) and cases in which it fails to satisfy a duty-imposing norm. See, for example, KeLsEn, GENERAL THEORY, supra note 12, at 192.

24. Id. at 189.

25. Examples abound of courts holding the state directly responsible for civil wrongs. See, e.g., Bivens v. Six Unknown Named Agents of the Federal Bureau of Narcotics, 403 U.S. 388 (1971); and Simpson v Attorney-General [1994] 3 NZLR 337 (CA) (N.Z.) (Baigent's Case). Reluctance to hold the state or state bodies criminally responsible is greater, but there is openness towards it in many jurisdictions. See, e.g., Criminal Liability of Corporations (Hans de Doelder \& Klaus Tiedemann eds., 1996), at 283, 297-299. 
constitutionally defective is not void ab initio but only voidable in the sense that it is valid law, and thus an act of state, until it has been annulled by a legally competent organ. ${ }^{26}$ Moreover, whereas Kelsen generally stands by the view that "no delict [or wrong] in the sense of national law can be imputed to the State," he also insists that the fulfilment of legal obligations-for example, obligations to repair the wrongs caused by individual state officials in connection with their official functions-can be attributed to state. ${ }^{27}$ According to him, it is only breaches of duties that cannot be so attributed.

Then again, complicating the puzzle, he sometimes seems to slip and concede, at the risk of self-contradiction, that the violation of certain legal obligations-with a focus on obligations of a financial nature "to be fulfilled from state property" - can be attributed to the state. Here his efforts at reconciliation are resolute, if somewhat perplexing. He argues that attribution to the state in such cases is "only a possible, not a necessary, mental operation," a legal fiction that can be abandoned for the more accurate characterization of a violation by individual officials to be fulfilled from the collective property of the members of the state. ${ }^{28}$

Thus, while Kelsen is receptive to the possibility of collective responsibility for domestic legal wrongs perpetrated in connection with the official functions of state organs, he resists, even if sometimes hesitantly, characterizing it as state legal responsibility (perhaps with one additional qualification, to be discussed in the next section). Here, as elsewhere, one could be tempted to try to tone down this claim by emphasizing that the scope of Kelsen's project is deliberately circumscribed to steer away from any sustained consideration of extralegal phenomena. He asserts that his argument is restricted to the development of a "pure," or wholly "normative," theory of law that "eliminate[s] from the object of the description everything that is not strictly law." $" 29$

Unfortunately for his defenders, Kelsen's methodological proviso fails to persuade with regard to his discussion of the state, given his frontal attack on the intelligibility of "impure" understandings. Not only does Kelsen consider but he also categorically discards such understandings as flawed: "There is no sociological concept of the State besides the juristic concept. Such a double concept of the State is logically impossible, if for no other reason because there cannot be more than one concept of the same object." ${ }^{30}$ Yet, taking him at his word, is it not precisely what he is himself arguing when asserting that conceptually speaking, state and law refer to one and the same object? Or could it be that Kelsen is here being too dogmatic, and that there is really something more "sociological" to the idea of the state-something

26. Kelsen, General Theory, supra note 12, at 157-158.

27. Id. at 200; Kelsen, PuRE TheORY, supra note 12, at 305-306.

28. Kelsen, Pure Theory, supra note 12, at 308-310.

29. Id. at 1; Kelsen, GeNERAL Theory, supra note 12, at 162.

30. Kelsen, General Theory, supra note 12, at 188-189. 
more than a mere "animistic superstition"31 - that disassociates it at least partly from the law and enables us to conceive of state legal departures? In the sections that follow, I want to begin to flesh out two related sets of replies that, although not uncontroversial, point, in my view, in the direction of an affirmative answer.

\section{B. Responsibility of the Incorporated State for Breaches of Legal Duties}

Legal and political theorists often refer interchangeably to state and government while also recognizing that we tend to conceive of governments as the embodiment of state agency. I propose to follow this usage for the time being, since it is also found in a challenging recent literature suggesting that states, or state-governments, and some of their institutional subparts can be nonfictional corporate agents irreducibly responsible for their own illegalities (and immoralities). ${ }^{32}$ Could such a line of argument falsify Kelsen's position? It is certainly in tension with it and, I think, warrants closer scrutiny.

Note, first, that the theorists in question do not deny that in a bid to legitimize their actions, state-governments tend to claim that everything they do is lawful. Since it is part of the concept of law that the law itself claims to be legitimate, such governmental claims are unsurprising. In fact, these theorists might even concede that the central case of state-government is a government that makes good on its claims and acts legally. What is more, they do not deny that a legal or, to be more precise, a constitutional normative order is essential for state-government agency-quite the opposite. What their position denies is that governments, qua duly constituted corporate agents, cannot conceivably act illegally (or, for that matter, immorally).

The gist of their position is that some groups of interacting human beings can be relatively autonomous agents-that is, that they can form intentional attitudes and perform concerted actions that are irreducible to the attitudes and actions of their members - thanks at least in part to the operation of a normative framework. Modern state-governments, which are made up of various (and often conflicting) institutional organs that are themselves relying on the agency of countless individuals, are often said to fall in this

31. Id. at 191 .

32. The most sophisticated defender of this position is Philip Pettit, who, in line with the usage described, tends to refer to "states" and "governments" in the same breath. See, e.g., P. Pettit, Responsibility Incorporated, 117 EтHics 171 (2007), at 199; C. List \& P. Pettit, Group Agency

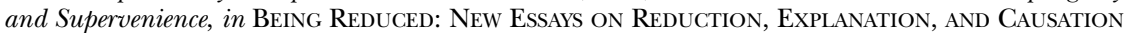
(J. Hohwy \& J. Kallestrup eds., 2008), at 1. See also P. French, Collective and Corporate RESPONSIBILITY (1984); and D. Copp, On the Agency of Certain Collective Entities: An Argument from "Normative Autonomy," in 30 Midwest Studies in Philosophy: Shared InTENTIONS ANd Collective RESPONSIBILITY (P. French \& H.K. Wettstein eds., 2006), the latter of whom prefers to stick with the term "state" to refer to the group agents in question. 
category. They all have a complex normative framework-that is, a constitution, written or unwritten-that constitutes and divides labor between their various organs, lays out principles of governance, and institutes authoritative decision-making, control, and review mechanisms. By jointly adhering to this framework to a reasonable extent, individual members allow their government qua corporate entity to form judgments and exhibit attitudes as a coherent whole and to make reasonably consistent decisions over time on the evaluative propositions (including ethical and legal propositions) that they present to it for consideration.

Some theorists describe the process by which the moral agency of individuals is constitutionally coordinated to give rise to irreducible governmental agency as a process of "institutionalization," "integration," or "conglomeration" that tends to survive specific individuals members and their political regimes. In his latest work on the topic, Philip Pettit further refines this claim. He notes that groups whose judgments depend on the judgments of more than one individual can be agents insofar as they respond rationally to their environments on a reasonably consistent basis. Constitutions facilitate group agency by assigning decisional roles to the group's individual members and setting limits on what they can and cannot do. To the extent that the group's constitution provides sufficient constraints against internal inconsistencies, the group operating under it may then be a relatively autonomous agent over time (despite deriving all its matter and energy from its individual human members). Pettit argues that constitutional constraints are sufficient for a group to be autonomous in this sense when they ensure that under normal conditions, reason is "collectivized" such that majority views do not always prevail and such that the group's attitudes cannot be described as a simple majoritarian function of the members' attitudes.

In Pettit's own words: "Autonomy is intuitively guaranteed by the fact that on one or more issues the judgment of the group will have to be functionally independent of the corresponding member judgments, so that its intentional attitudes as a whole are more saliently unified by being, precisely, the attitudes of the group." ${ }^{33} \mathrm{He}$ also insists that decision procedures must be in place to guarantee that the group can change and correct its irreducible attitudes, so as to ensure rational unity and consistency. State constitutions often ensure such governmental autonomy over time by imposing a variety of balances and checks on governmental decision-makingseparation of powers, bicameral legislatures, federal division of powers, bills of rights, judicial review, stare decisis, elections, impeachment procedures, and so on. Depending on how they are constituted, discrete institutional corporate organs of government pertaining to its executive, legislative, or judicial branches-sometimes at both federal and state, or provincial, levels_-can also be imbued with such relatively autonomous 
agency. In this sense, modern state-governments are admittedly "artificial agents" or "creatures of law"-law does play a crucial role in constituting and regulating the apparatuses that enable their agency (and, conceivably, the agency of their institutional corporate subparts). ${ }^{34}$

However, even if, according to this line of argument, law plays a pivotal role in constituting state-governments as irreducible agents, this concession in no way implies that they are exclusively creatures of law. In fact, pace Kelsen, such an inference seems unwarranted. In addition to being creatures of law, state-governments are also sociopolitical creatures partly constituted by the contributions, practices, attitudes, and persistent commitment of their individual members as well as by nonlegal norms such as constitutional conventions. ${ }^{35}$ Specifications of the notion of state-government in narrow legalistic terms generally fail to give due regard to these extra dimensions. ${ }^{36}$ So we should not be misled into thinking that insofar as governments are partly constituted as agents by law, they are to be equated with it and cannot intelligibly contravene it. On the contrary, once constituted as agents, stategovernments may conceivably do all sorts of illegal (and immoral) things de facto.

To be sure, one may question the extent to which a government can act illegally on the additional ground that whatever a state-government does is ultimately done by individuals acting on its behalf. That is, to the extent that it is individuals who perform governmental deeds, are they not really the ones acting illegally? When arguing that state-governments can conceivably depart from the law, theorists such as Pettit are not denying that individuals may have to answer personally to the law (or, for that matter, to morality) and bear adverse normative consequences for what they do as enactors

34. Of course, this is only part of the story. "Quasi-states" may not have a sufficiently developed constitutional apparatus, and even when they do, their individual members may not comply with it enough for them to qualify as full-blown autonomous corporate agents. Can the position discussed here be extended beyond the most successfully "detached" and "neutral" liberal democratic governments? As Toni Erskine reminds us, one ought to exercise a great deal of caution before prematurely dismissing quasi-states as "failed states" unable to exercise relatively autonomous moral agency. Many of them may, in fact, have all it takes to exercise such agency. Although I cannot explore the point further here, it may also be the case that institutional corporate moral agency comes in degrees. T. Erskine, Assigning Responsibilities to Institutional Moral Agents: The Case of States and "Quasi-States, "in CAN INSTITUTIONS HAVE RESPONsibilities: Collective Agency and International Relations (T. Erskine ed., 2003), at 29-31. Now, given that my present focus is on the conceptual possibility of state-governments genuinely departing from the law, the possibility of relatively autonomous governmental agency suffices for my argument.

35. On the constitutional nature of constitutional conventions qua nonlegal social rules regulating "the mode of conduct of government," see J. Jaconelli, The Nature of Constitutional Convention, 19 LEgal STUdies 24 (1999). Note, however, that for the sake of simplicity, I continue to use "constitutional law" and "constitution" quite interchangeably unless the context makes the distinction clear.

36. For a lucid account of how real-world constitutions tend to have both legal and sociopolitical components such that it is unwise to seek to account for them in wholly legal or political terms, see G. Gee \& G. Webber, What Is a Political Constitution?, 30 Oxford J. Legal Stud. 1 $(2010)$. 
of a governmental deed. They simply contend that a state-government qua corporate agent can also be "fit to be held [legally and morally] responsible" as "the source of that deed: the ultimate, reason-sensitive planner at its origin." 37

A short exercise in disambiguation may help clarify this use of the term "responsible." Responsibility theorists tend to argue that one must be "responsible" in a basic sense before one can violate norms (and thus perpetrate wrongs). They also often argue that one must at least be assumed to be responsible in this basic sense before one can intelligibly be "held responsible" in the sense of being singled out by the law or by morality to bear the adverse normative consequences of such violations. ${ }^{38}$ The basic responsibility in question is the ability, or "fitness," to recognize and respond appropriately to reasons (including norms), and is a concomitant of rational agency. According to the position under consideration, state-governments' constitutions may enable them (as well as some of their institutional corporate subparts) to process reasons for action systematically and form judgments that are irreducibly their own, despite the need to draw on the resources of their individual members to do so. State-governments can then plan for action on the basis of their own judgments, identify some individuals as agents to perform required tasks, and more or less ensure that they perform them in the relevant manner. In other words, state-governments (and some of their institutional corporate subparts) may control in a reason-sensitive way for the performance of certain actions by individuals who act on their behalf. The thought is that they are fit to be held responsible for what they control in this way. They can arrange for illegal and immoral things to be done or participate in doing them and, just like individual agents, they can intelligibly be singled out to bear adverse normative consequences as a result.

Admittedly, this understanding of government as the "source" of illegal and immoral deeds needs to be fleshed out further. Pettit's remark that a corporate entity such as a state-government can be held responsible for what "it arranges to have done, given the decisions it licenses and the constitution by which it channels those decisions," suggests that he has in mind a relatively direct form of attribution of consequential responsibility for wrongdoing. ${ }^{39}$ When, for example, a government "arranges" for individuals to perpetrate acts of torture by specifically delegating that task to them, it

37. Pettit, supra note 32, at 192.

38. The contrast I have in mind is akin to the one that H.L.A. Hart draws between "capacityresponsibility" and "liability-responsibility" and that J. Gardner refines using the labels of "basic responsibility" and "consequential responsibility." See H.L.A. HART, PUNISHMENT AND Responsibility: Essays In the Philosophy of LaW (1968), at 227-228; and J. Gardner, Hart and Feinberg on Responsibility, in The Legacy of H.L.A. Hart: Legal, Political, And Moral Philosophy 143-164 (M.H. Kramer et al. eds., 2008). I use the expression "holding responsible" to refer specifically to the imposition of consequential (or liability) responsibility by the law and morality (as well as, conceivably, norms of other kinds).

39. Pettit, supra note 32, at 196. 
operates, quite literally, as the ultimate reason-sensitive "source of the deed." A similar analysis may apply to broader governmental licenses and authorizations. A government that empowers officials to torture on its behalf no doubt exercises a significant degree of control over the perpetration of torture. To the extent that Pettit's account is sound and that legal and moral duties are violated in the process, I see no reason to believe that the government in question can never conceivably be held consequentially responsible in law as much as in morality (in addition to the individual perpetrators). If it is wrong to torture people, it is also wrong for governments to instruct and empower people to torture on their behalf. Thus Pettit would no doubt criticize someone like Dyzenhaus, who seems to suggest along Kelsenian lines that legal responsibility in cases of torture can lie only with "private individuals," for failing to address this kind of possibility. ${ }^{40}$

Of course, even on the basis of Pettit's account, when officials violate duties without clear governmental authorization, it is not always obvious that their government has done anything wrongful. The individuals in question may be the ultimate sources of their own deeds. Given that Dyzenhaus argues that torture should never be officially condoned either ex ante or ex post facto, this may be the point that he is trying to convey. To be convincing, though, the point must be refined. In many situations in which individual officials violate duties while acting without governmental license, there may still be a question of accessorial governmental wrongdoing. For example, a government may have provided individuals with the opportunity to violate various duties, without per se empowering them to do so. It may, say, have required police officers to patrol a peaceful demonstration dressed in uniform, batons in hand. If they then run amok, beating innocent protesters and detaining them capriciously, their government may not be in a position to deny all responsibility. It may be held responsible for wrongfully failing to control conduct that it should (and often was legitimately expected to) have controlled or for wrongfully aiding or procuring it. In other words, it may be held responsible as an accomplice.

Here there is really no need for a theorist like Pettit to deny that Dyzenhaus and Kelsen's concern has some grounding in truth. There is likely a point at which wrongs perpetrated by public functionaries are so severe, so extraordinary, and so unconnected to their official roles and functions that it would make little sense to talk of state-governments as a wrongdoers in relation to them (except perhaps vicariously). But, as Pettit would surely caution us, we should be careful not to jump too hastily to this conclusion.

What should we make of this account? On the plus side, it sensibly dodges Kelsen's criticisms directed at those who mysteriously characterize group entities such as states or substate corporate agents as "superhuman beings." 41 For Pettit, any sound account of irreducibly responsible group agents must

40. Dyzenhaus, Compulsion of Legality, supra note 2, at 54-55.

41. See, e.g., Kelsen, General Theory, supra note 12, at 108, 184-186. 
recognize that human beings are at the root, forefront, and center of their existence and of everything they do-that is, individual humans provide all their matter and energy, so that they are only "relatively" autonomous. Pettit's ontological assumptions are fundamentally individualistic and are compatible with value humanism, according to which the value of anything, including group agency, ultimately derives from its contribution to human life and its quality. One could also point out that his account has the advantage of providing a distinct ground for holding groups such as stategovernments responsible-say, because their actions or organization made harm likely or inevitable-when no similar ground is available for holding individual contributors responsible. Such shortfalls of individual responsibility may arise when, for example, individual contributors to governmental action avoid being held responsible for their acts owing to reasonable mistakes or ignorance, due care, duress, or other relevant factors. Legal regimes of state responsibility may guard against such scenarios as well as diminish the incentive to arrange things so as to increase their likelihood.

Still, some major questions subsist, of which I can unfortunately only scratch the surface here. For example, as recent work in the theory of individual excuses has sought to demonstrate, the exonerating force of epistemic limitations and other types of pressures inherent in organizational settings is arguably less significant than has traditionally been believed. ${ }^{42}$ One salient reason for this skepticism is as follows: insofar as individuals know-or, perhaps, should know - that they are participating in the operation of a group decisional framework that may, by its very constitutional design, yield bad or harmful outputs, it is questionable whether they should ever be able to escape consequential responsibility by invoking the irreducibility of these outputs.

If this reasoning is sound, the shortfall of individual responsibility argument may not provide as compelling a case for regimes of group responsibility as Pettit thinks it does. Furthermore, if one digs deeper into the details of his argument for irreducibility, one cannot help but notice the stringency of its foundational rationale. As suggested above, Pettit contends that a group displays irreducible agency when it "collectivizes reason" in its formation of judgments, in the sense that it brings together individual judgments in ways that may bring its overall judgment on some particular matters into disaccord with the judgment of the majority of its individual members. Pettit claims that for such discrepancy to be possible, the group's constitution must require individual members to aggregate their judgments on each premise of a decision rather than aggregate their final judgments on the overall decision. He also allows for more complex

42. See, e.g., J. MCMAHAN, KiLling IN WAR (2009), at 131-154. McMahan's insightful challenge of soldiers' claims of excuses for their decisions to fight in unjust wars, on the basis of epistemic limitations and pressures inherent in their military and social position, is a case in point. Still, much theoretical work remains to be done to elucidate organizational and corporate excuses in all their complexity. 
"distributed premise-based procedures" where different subgroups specialize on judging specific premises, so long as ultimate group judgments are constituted by aggregated judgments on separate premises as opposed to overall decisions. ${ }^{43}$

While it is at least plausible that many state-governments, considered holistically, with all their internal balances and checks, are constituted in ways that normally satisfy this requirement, specific governmental organs such as courts, legislatures, ministerial cabinets, and administrative agencies may well not be so constituted. It cannot simply be assumed, as Pettit sometimes seems inclined to do, that these governmental organs, or even state-governments considered as wholes, will be agents capable of being held responsible in an irreducible sense.

In the end, though, the most powerful challenge for this robust way of thinking about state legal responsibility might be thought to reside in Kelsen's work itself. Indeed, insofar as it is just (or otherwise justified) to hold a group responsible for a breach of legal duty, can the law not simply treat the group as if it were per se capable of this breach? Kelsen would probably insist that recourse to such legal fiction, whatever else we may say about it, is much less obscure, counterintuitive, and difficult of application than a more organic approach like Pettit's. It is true that Kelsen is uncomfortable with the idea of state legal wrongdoing and that insofar as he comes close to recognizing it, he goes out of his way to relate it back to the wrongs of certain individual officials-not state-governments or their institutional corporate subparts. Yet, as I mention above, he is also receptive to the possibility of some form of collective legal responsibility, of which he speaks primarily in terms of a legal fiction-that is, the corporate "juristic person," which he characterizes as "a group of individuals treated by the law as a unity, namely as a person having rights and duties distinct from those of individuals composing it." ${ }^{44}$ Such a fictional entity, he explains, is unified by a specific system of norms - a "partial legal order"-regulating the behavior of individual members and serving as the common point of imputation for all human acts that are determined by it. ${ }^{45}$ When such acts violate duties that the law imposes on the corporate juristic person, they result in wrongs (or "delicts") that are intelligibly, if only fictionally, attributable to it.

The key point to note here is that Kelsen asserts that "a delict which is a violation of national law can be imputed to any ... juristic person within the national legal order." 46 Albeit commonly overlooked, this general acknowledgment seems to extend to any corporate organs of government recognized by law as well as to the state-government holistically considered, which Kelsen occasionally refers to somewhat surprisingly as "the

43. These conclusions come primarily out of Pettit's treatment of the well-known discursive dilemma. See List \& Pettit, supra note 32, at 80-88.

44. Kelsen, General TheOry, supra note 12, at 96 (emphasis added).

45. Id. at 99-100.

46. Id. at 199 (emphasis added) . 
State ... distinguished by a material criterion. ${ }^{47}$ Parting momentarily with his otherwise monolithic understanding of the state, Kelsen concedes that the bureaucratic apparatus of the state-comprising all its machinery and individuals officials-is itself a "partial legal order," just like any other corporate juristic person. As a result, it is at least open to question whether he would deny the intelligibility of ascriptions of breaches of legal duties to the state, so understood.

Of course, additional considerations, such as considerations of justice and practicality, may affect the kinds of wrongs for which the law may legitimately hold state-governments and their institutional corporate subparts responsible and what sorts of consequences it may impose on them as a result. For example, the possible repercussions of group censure and punishment on innocent individual group members and the individualistic nature of the rights around which the criminal process is characteristically structured often lead to greater reluctance to hold governmental (and other) groups criminally rather than civilly responsible.$^{48}$ However, my focus is here on questions of intelligibility, not on questions of legitimacy, and the fact is that Kelsen, like Pettit, has no qualms about the conceptual possibility of holding governmental (or other) groups civilly or criminally responsible. Admittedly, some readings of his work invite doubts about the intelligibility of processes required to hold a state-government as a whole responsible for breaches of domestic legal duties, insofar as such processes will likely themselves involve state courts and, in criminal matters, state prosecutorial and penal authorities. But one should be careful not to move too fast. Although admittedly a controversial position, if one allows that private arbitrators may preside over civil cases and that private prosecutions and punishments are at least conceivable, then the objection loses some of its force. ${ }^{49}$

Furthermore, nemo judex in causa sua is first and foremost a principle of justice, not a conceptual necessity as this argument implies. Finally, even if we concede the objection arguendo, it remains the case that distinctively public governmental organs can intelligibly be held legally responsible for wrongdoing, if not irreducibly then at the very least fictionally.

Recall that what Kelsen is at pains to deny is that legal wrongs can conceivably be attributed to the state understood as the legal order. However, as my discussion of Pettit's work starts to suggest, there is likely more to the idea of "the state" than law. In fact, as Kelsen himself begins to recognize when talking of a secondary "material" sense of state, we may not even need to think of the state in robustly irreducible sociolegal terms to see this. Yet his narrow legalistic commitments prevent him from making this concession outright.

47. Id. at 194 .

48. C.f. D.F. Thompson, Criminal Responsibility in Government, in Nomos XXVII: CRIMINAL Justice (J.R. Pennock \& J.W. Chapman eds., 1985), at 210-214, 223-226.

49. Those who believe that a monopoly on the legitimate use of force is a (or "the") mark of the state might cringe at such a suggestion. I, for one, tend to think that this claim is generally inflated and that to exist, a state must only monopolize some relevant uses of force. 
His theoretical focus is on legal norms, which generally leads him to reject rather rashly any talk of the state in terms that seek to capture its sociopolitical dimension-such as state-government, body politic, or res publica. A more promising argumentative trajectory is no doubt that of those who seek, or also seek, to account for this additional conceptual dimension by characterizing the state as the political organization of society - that is, the public, institutional, and territorial organization of a society's governance which, although not exclusively, is significantly constituted by law (and minimal respect for it), and whose exercises of power can themselves be both legal and extralegal. ${ }^{50}$

While the main criticism of such accounts is that their parameters are too messy, uncertain, and contested to have any theoretical purchase, their proponents should not be deterred on such grounds. ${ }^{51}$ Conceptual contestability often reflects the complexity of our social, political, and legal landscape, and a sound conceptual account should not strive to conceal it.

When seeking to hold the state, so understood, responsible for breaches of duties-either as an irreducible agent or through recourse to a fictionthe law may help cure doubt at the edges, as it does in respect of so many other hazy sociolegal realities, by sharpening its boundaries authoritatively. To borrow an example from Canadian criminal law, an administrative agency or local government may sometimes be singled out and charged as a genuinely "public body," rather than a mere private "body corporate," to reflect its direct connection to the political organization of society. ${ }^{52}$ Granting the intelligibility of possibilities of this sort seems all the more important given the numerous reasons which, although contentious, might justify or even morally require holding the state civilly or criminally responsible for the acts of those who act in its name and behalf-for example, censure of public complicity in wrongdoing, greater structural and political incentives to exercise due care, more effective deterrence against widely countenanced abuses carried out in the name of the state or the public by those holding constitutionally defined offices or those having control over them, avoidance of shortfalls of accountability, vindication of legitimate expectations, reasons of desert or of expressive symbolism, and so forth. ${ }^{53}$

50. See, e.g., N. MacCormick, Questioning Sovereignty (1999), at 25-26.

51. This insight underlies much of the argument in Gee \& Webber, supra note 36, about the need to grapple with Britain's "political constitution" as well as its "legal constitution" to understand its nature as a state.

52. Both of these characterizations of "organizations" are, at least in principle, available to Canadian prosecutorial authorities under the Criminal Code, R.S.C. 1985, c. C-46, s. 2, 22.1, 22.2. See also S.P. Green, The Criminal Prosecution of Local Governments, 72 N.C. L. REv. 1197 (1994); note 25 supra.

53. Of course, some of these purportedly justificatory reasons may cut both ways. For example, Joel Feinberg conceives of criminal condemnation and punishment for wrongdoing as symbolic acts of "disavowal" by which the world is told that the perpetrator of a crime "was on his own doing it, that his government does not condone that sort of thing." J. Feinberg, The Expressive Function of Punishment, 49 THE MonIST 397 (1974), at 404. 
Understanding the state in socio- or politicolegal terms makes such discourse intelligible in a way that a pure adequation of state and law does not. ${ }^{54}$ It allows us to conceive of the attribution of legal wrongs to the state, and to do so even when, strictly speaking, such wrongs are perpetrated ultra vires.

Now, one might be tempted to interpret what I say above as leaving the core of Kelsen's normative theory of law intact. All that would be required for this to be the case, one might think, is for him to acknowledge outright that there is a sense of "the state"-perhaps an additional sense-that differs meaningfully from the legal order, even if deeply interconnected with it, and that makes state illegality intelligible. Thomas Hobbes, who, like Kelsen, equates state-or, rather, Leviathan-and law for normative purposes, may be seen as gesturing in this direction when he holds that conceptually speaking, a commonwealth's body politic, or monarch, can act illegally. ${ }^{55}$ The point is important and should not be lost upon theorists, and perhaps especially emergency theorists, who engage with the recent work of scholars such as David Dyzenhaus who purport to build on Kelsenian and Hobbesian insights about "the state" without sufficiently demystifying them and their methodological grounding in the first place.

Then again, one should be careful not to conclude too hastily that when interpreted as I do here, Kelsen's work adequately addresses all key concerns that animate theorists of group responsibility. Consider the following point in particular. As I suggest above, Kelsen sometimes insists that even insofar as legal duties and their breach can fictionally be imputed to corporate entities such as the state, at bottom the only "real" duties and breaches are those of individuals. In the last analysis, he claims, only individual human beings' actions can really fall under the scope of a legal norm: "The obligations and rights of a legal person [be it corporate or noncorporate] must be broken down into obligations and rights of human beings, that is, into norms governing human behavior, establishing certain human acts as obligations and rights. ${ }^{56}$ So, even insofar as Kelsen can allow that state legal wrongdoing is conceivable, he also insists that it is always reducible to individuals' wrongdoing. In view of this commitment, it is easy to understand why he can make sense of the idea of state legal wrongdoing only as a fiction: it adds nothing to the fact that individuals are always the real

54. What is more, if the modus operandi of state legal responsibility is a legal fiction and, as Lon Fuller writes, "[a] fiction becomes understandable only when we know why it exists," then reasons like those listed may well bolster its understandability. See L. Fuller, LEGAL Fictions (1967), at 49-50.

55. T. Hobbes, Leviathan (1996), at 150 (ch. 22, para. 9-10). Perplexingly, Hobbes also sometimes claims that the sovereign of a commonwealth, individual or body politic, is not subject to the civil laws ( $i d$., ch. 26, para. 6). However, this claim is best understood as a claim about Hobbes's preferred constitutional arrangement for the commonwealth-i.e., a monarch or assembly against whom citizens have no effective rights-which could intelligibly be different.

56. H. Kelsen, Introduction to the Problems of Legal Theory (1997), at 49. 
subjects of legal duty-imposing norms and that it is always their individual violations that are the true matters of concern.

Yet, if Pettit is right that at least some group actions are irreducible to the actions of the group's individual members and that states and state corporate bodies can act in such irreducible ways, then it is at least conceivable that duty-imposing norms may be directed at the state's irreducible actions themselves. State legal wrongdoing may then not be or not always be purely fictional. Notice also that even if one concedes, arguendo and pace Pettit, that states and state corporate bodies are ultimately unfit to be held responsible per se for their irreducible wrongdoing, and that resort to fictions of responsibility remains unavoidable for such holdings to be intelligible, Kelsen's model may still be inadequate to the extent that genuinely irreducible state (qua group) actions and norm violations are conceivable. An explanatory tertium quid between Kelsen's individualistic fictionalism and Pettit's robust model of group responsibility may then be required to account for the possibility of irreducible collective action (including irreducible state action) and group-directed (including state-directed) duty-imposing norms.

\section{States as Unconstitutional Actors?}

So far, I have been focusing mostly on state breaches of legal duties, contending that given an appropriate understanding of the state, they are conceivable even if perpetrated ultra vires. Now, even on the assumption that this stance is accurate, one might here interject that insofar as it is at least partly constituted by law, the state cannot intelligibly violate its constitutional law. The state, it may be thought, cannot intelligibly violate the very law that constitutes it without denaturing itself in the process. It is easy to see why such a line of reasoning would be appealing to those who, like Kelsen, believe that law is the state's quintessential unifying feature, all the way down. Yet, as I began to argue in the previous section, I think this approach is unduly dogmatic and, as a result, misleading. I now want to bolster my case by showing briefly, in a way that challenges Kelsen's legalistic approach more fundamentally, that there is some key sense of an abiding sociolegal state of which we can speak intelligibly of as acting in a constitutionally unauthorized fashion.

Consider first the following scenario. A state's parliament or congress enacts an unconstitutional law that is subsequently recognized by the executive, enforced by all the courts, and accepted by the population. If the law has little constitutional importance (e.g., if it regulates the manufacture of staplers), I see no reason to think that it is not the very state that adopted it that is contravening its constitution. A defender of Kelsen may retort that this insight can be explained by the fact that the law in question is not really unconstitutional since it has not been annulled by any legally competent organ-that is to say, it is not really invalid but merely voidable. Yet this 
cannot be the end of the story. There is an important sense in which if the constitutionally defective law continues to be interpreted and applied in the "incorrect" manner by all relevant parties and this new understanding becomes entrenched, the constitution will have been departed from or modified in the process. In such cases, it may be more accurate to say that the constitution has changed or been departed from, even if only minimally, while the identity of the state and, for that matter, the legal system as a whole has not been altered. My claim that there is more to the state than its constitutional law helps makes sense of this intuitively appealing position.

To clarify the matter, it is useful to push the inquiry further: What if the unconstitutional law adopted above were constitutionally significant? In such cases, it is certainly more plausible to think that the continuity of the state's identity is disrupted. If a fundamental marker of the state's identity is significantly flouted, it seems reasonable to ask whether what remains thereafter is the same state or sometimes even any state at all. The question, then, could be reframed as follows: At what point on a spectrum of unconstitutionality does it become more accurate to speak of acts attributable to a new state (or, alternatively, of nonstate actions)?

To some extent, legal theorists began to address the issue decades ago when discussing revolutions and coups d'état. John Finnis and Joseph Raz, whose work is perhaps most relevant here, both agree that the answer cannot be a mere matter of law. Their main reason for making this claim seems unassailable. In Finnis's words, social rules, be they legal, prelegal, conventional, or otherwise, "have no common identity or basis for existence in time save that of the group of human beings which accepts them." 57 The reasoning underlying this conclusion is that any set of social rules, such as the rules making up "a constitution," is subject to change over time. Therefore, when considered diachronically, a constitution must inevitably be understood as a sequence of sets of rules. We think of this sequence of sets as a unified constitution only because the ongoing group of human beings to which it belongs accepts it as an efficacious and continuous unit.

Of course, if a state's constitution-holistically understood as the set of norms, both legal and conventional, that organize it-is widely disregarded, then the continuity of this state is a nonissue. There is no state in the first place. However, an implication of Finnis's point seems to be that so long as a sufficient constitutional framework subsists and is recognized, accepted, and followed to a reasonable extent as if the same by the relevant human grouping, which we may call the political community, then the identity of the state constituted by it remains continuous (perhaps subject to some limited exceptions). Given what I say above about the inevitable significance

57. J. Finnis, Revolutions and Continuity of Law, in OXFORD EsSAYs In JuRISPRUdenCE: SECOND Series (A.W.B. Simpson ed., 1973), at 70. See also J. Raz, The Concept of a Legal System (2nd ed., 1980), at 188-189, 210-211. 
of sociopolitical considerations to the existence and organization of states, this conclusion should come as no surprise.

One important consequence of this line of reasoning is that the continuity of a state will sometimes be interwoven with considerations of realpolitik, as demonstrated by countless cases of secession and decolonization in the last century. Of course, there may be allegedly "legal" avenues to make the cutoff point between the same and new states sharper. For example, courts sometimes seek to bring the conduct of a usurper regime in line with a preexisting constitution by drawing on all sorts of purportedly legal techniques.

One case in point is the 1999 decision of the Supreme Court of Pakistan affirming the existence of a doctrine of state necessity in Pakistani constitutional law and applying it to deny the claim that the army had created a new legal order by overthrowing democratically elected officials and proclaiming a state of emergency. ${ }^{58}$ In another recent case, Republic of Fiji v. Prasad, the Court of Appeal of Fiji invoked an unprecedented principle of efficacy, this time finding against the de facto rulers of the country and insisting on a restoration of the previous constitutional order. ${ }^{59}$ Yet the crucial point here is that the impact of these decisions on the states' identities was necessarily related to the political strength of the courts making them, as reflected in the acceptance or rejection of the decisions by the rest of the political community.

This point could probably be extended to most scenarios of significant constitutional turmoil. Even if, as a result, it will often be difficult to predict the precise point on a spectrum of unconstitutionality at which a given state will cease to exist, such uncertainty does not entail that states cannot act unconstitutionally. On the contrary, significant unconstitutional actions often fail to undermine the identity of states, which can even sometimes be praised or criticized for them when there is a moral issue at stake. There is no conceptual impediment to states being thought of in this way. To be sure, it is true that in the context of a coup, acts contrary to prevailing constitutional norms will often become constitutionally authorized in some sense. For example, an allegedly legal yet also clearly political pronouncement may hold sway, as in the Pakistani predicament discussed above, or the constitution may be modified ex post facto to legalize illegality. However, the ultimate test for determining the identity of a state is not legal recognition in this secondary sense. It is, first and foremost, persistent recognition by the relevant political community.

One appealing corollary of this understanding is that it makes intelligible the widely held assumption that constitutions are not "suicide pacts" that states must necessarily uphold in all their facets if they are to subsist. This

58. Zafar Ali Shah v Pervez Musharraf, Chief Executive of Pakistan, (2000) 52 PLD (SC) 869 (Pak.).

59. Republic of Fiji v Prasad, [2001] NZAR 385 (CA) (Fiji). 
outcome is salutary, given the long judicial and theoretical lineage of the assumption. ${ }^{60}$ Even a thinker such as Immanuel Kant, who deduces from a priori principles the intrinsic necessity of a staunchly inflexible constitutional separation between the legislative (sovereign), executive, and judicial powers (Gewalten) of the state, recognizes the conceptual possibility of unconstitutional derogations by states. For example, he argues that whereas in an ideal world no one would ever usurp the function of the judicial power, the sovereign may do so in a "case of necessity," when rigorous compliance with the legal framework would cause the state to dissolve into a "state of nature, which is far worse because there is no external justice at all in it." ${ }^{\prime \prime}$ To be even more specific, he claims that if the judicial power were ever required by a priori principles to sentence so many people to death as to endanger the stability of the state, the sovereign should be able to "pronounce a judgment that decrees for the criminals a sentence ... which still preserves the population." He insists that such a pronouncement "cannot be done in accordance with public law but [that] it can be done by executive decree that is, by an act of the right of majesty." ${ }^{\prime 2}$

The line of criticism briefly elaborated in this section is no doubt more damaging to Kelsen's overall project than the one developed in the previous section. It purports to show that a purely legalistic understanding of the state is unable to account for the state's existence through time, whether it is understood as the legal order itself or, more materially, as state-government. Something else is needed to provide diachronic unity to the state. That something else, I suggest above, is the ongoing common identity of the political community, whose persistent recognition of the state's constitutional framework, acceptance of it, and abidance by it provides the state with its life and blood. It is because Kelsen lacks the concept of a political communityor what John Austin gestures towards when referring to "an independent political society"63 - in which states find their very real and tangible roots that he is unable to account satisfactorily for their continuity. Only after this concept has been at least partly explained in nonlegal, sociological terms does it become possible to explain the persistence of states (and, one might add, legal systems) through time.

Of course, "political community" is itself a hazy concept—perhaps just as much as the notion of "nation," often invoked to single out a community of people bound by common ancestry, history, or tradition who seek to

60. For judicial pronouncements, see Application under s. 83.28 of the Criminal Code (Re), [2004] 2 S.C.R. 248 II6 (Can. Sup. Ct.); Attorney Gen. of the Republic v. Mustafa Ibrahim, [1964] Cyprus L. Rep. 195 at 237 (Triantafyllides, J.) (C.A.) (Cyprus); Kennedy v. MendozaMartinez, 372 U.S. 144, 160 (1963); Terminello v. City of Chicago, 337 U.S. 1 (1949), 37 (Jackson, J., dissenting). For an interesting theoretical discussion, see J. FinNIS, NATURAL LaW AND NATURAL Rights (1980), at 275.

61. I. Kant, The Metaphysics of Morals (M. Gregor ed., 1991), at 107. Compare with Kant's exposé on the three powers (also translated as "authorities") of an ideal state; id. at 90-95.

62. Id. at 107-108.

63. J. Austin, The Province of Jurisprudence Determined (1954), at 192-193. 
govern themselves with a set of political institutions. ${ }^{64}$ But the haziness is deliberate: I am using the concept merely as a way of conveying the possibility of a sufficient degree of diachronic group identification, as well as ongoing recognition and support for a constitutional framework, by a given population, its officials, and relevant international actors.

As a more detailed account, replete with its unavoidable complexities, would needlessly detract from my argument, I shall refrain from saying any more here and await another more appropriate occasion. I shall only add in passing that some theorists think that moral constraints must supplement the ongoing social existence and attitudes of the political community in any complete explanation of the continuity of states. They speak, for example, of the need for an "ethically reasonable" allegiance to the state's constitutional order. ${ }^{65}$ I very much doubt the helpfulness of this extra move. It seems rather gratuitously restrictive from an explanatory standpoint and moreover risks dragging us back into the type of conflation of the conceptual with the moral from which I sought to steer clear in Section I.A. Besides, this extra move is unnecessary to convey the force of the more limited point I seek to make, which is that, pace Kelsen, exercises of powers conferred by constitutional norms, as well as by legal norms more generally, are not-and cannot bethe be-all and end-all of the life of the state.

\section{SOME CONCLUDING THOUGHTS ON THE MEANS AND AUTHORITY OF THE STATE}

Could it be that when he writes that actions taken "outside the law" cannot be those of a state, Dyzenhaus, who departs from Kelsen's work in other respects, is making a different or further claim from the one I have been discussing so far? Perhaps he means that states and their agents cannot conceivably act by nonlegal means. Indeed, he sometimes ambiguously remarks that "the state's authority has to be exercised through law." 66 This interpretation of his position is odd, since as citizens we regularly witness our officials' attempts to guide us in the name of the state through nonlegal means. They often advise us, entice us, or exhort us to act in certain ways. In fact, as Leslie Green remarks, "probably no state could function if law were its only resource in guiding action. . . . In some circumstances, nonlegal

64. For similar formulations, see Y. TAmir, Liberal NATionalism (1995), at 63-69; K.A. APPiah, The Ethics of Identity (2005), at 244. For further definitional complications, see M.C. Nussbaum, The Clash Within: Democracy, Religious Violence, and India's Future (2007), at 10-16.

65. See especially Finnis, Revolutions, supra note 57, at 76. Since I discuss an aspect of Immanuel Kant's conception of the state above, it is perhaps also worth noting that Kant, also, understands the diachronic unity of the state in a deeply moralized, though differently conceived, way. Relevant insights can be found in A. RIPSTEIn, ForCE AND FREEDOM: KANT's LEGAL AND Political Philosophy ch. 11 (2009).

66. Dyzenhaus, Compulsion of Legality, supra note 2, at 37 (emphasis added). 
requirements may even be preferred where legal regulation would be inefficient, self-defeating, or symbolically inappropriate." ${ }^{67}$ So nonlegal state action is commonplace, and it is doubtful that Dyzenhaus means to deny this.

Perhaps, then, what Dyzenhaus really wants to emphasize is that when a state does not act "through law," its acts have no authority. However, even this additional thought seems misguided. It is true that state agents commonly resort to law as a means of guiding the behavior of the governed. In fact, it is their primary means of doing so. It is also true that rules of law are, or are claimed to be, authoritative rules that guide the behavior of their subjects by providing them with content-independent, binding reasons to act. Yet states sometimes provide reasons that do not derive their authority from a legal system. For example, they may indicate or invoke the existence of independently authoritative reasons emanating from individuals and organizations that are held to have deeper moral insight, special expertise, or unique coordination ability and are generally treated (and sometimes legitimately so) as practical authorities.

Consider, along this line, the South African government's frequent invocations of Nelson Mandela's pronouncements or references by U.S. state officials to the words of the Founding Fathers as authoritative reasons for action. Think also of state appeals to directives from the World Health Organization as authoritative guides in times of pandemic. Moreover, states may, through their agents, claim to provide practical guidance that is more robustly authoritative in virtue of the fact that they are the ones providing it. Even when this guidance is legally invalid-because it stems from some ultra vires act - it may still be treated as authoritative by its addressees (i.e., as guidance that is binding for the reason that it emanates from the state). So guidance that is not strictly speaking guidance "through law" because it is legally invalid, yet is attributable to a state (understood in sociolegal terms), may still have de facto authority over its addressees. To the extent that such de facto authoritative guidance makes it more likely that its addressees will comply better with reason by conforming to it than by following their own lights—say, because of the state's better coordination position—it may even be legitimately authoritative. ${ }^{68}$

Finally, building on the argument of the last section, if the diachronic identity (and thus existence) of state and law is indeed contingent on the common identity of and recognition by the relevant political community, then there is only a small step to the contention that the authority of state and law through time cannot be traced back to the law itself, or at least

67. L. Green, The Authority of the State (1990), at 77. Green gives the example of a system of prices and incomes restraints that may be justifiable only in the absence of administrative costs associated with its legal imposition. He also points to systems of voluntary restraints that by definition cannot be legally imposed.

68. See generally J. Raz, The Problem of Authority: Revisiting the Service Conception, 90 MinN. L. REv. 1003 (2006), on the normal justification of authority. 
not entirely so. If this inference is correct-and I cannot defend it further here-Kelsen's purely normative approach to theorizing law and whatever Dyzenhaus makes of it may need to be rethought, or at least significantly supplemented.

If we are to make any sense of a position such as Dyzenhaus's, I think we must understand it as something more than a mere set of descriptive and conceptual claims about states and their authority. We must approach it for what it really is: a morally laden normative thesis. At that level, many important questions subsist. For example, when are states really bound by law? Should or may they ever legitimately depart from it? Insofar as they do contravene domestic law, how should they be held accountable? Should the law itself seek to play that role, and if so, under what guise-public, civil, criminal, public international, or international criminal law? Should we bank instead on nonlegal restraints such as social and political mores or direct action by "the people" (or the political community more broadly understood)? These are all important and complex questions that are receiving an increasing amount of attention nowadays from theorists studying the implications of public emergencies for state and law. This interest should come as no surprise, since public emergencies are fertile grounds for state illegality. Kelsenian conceptual dogmatism and Dyzenhaus's puzzling extrapolations on the same theme should not be allowed to preempt or otherwise distort their important efforts.

\section{REFERENCES}

Appiah, K. A. (2005) The Ethics of Identity (Princeton, NJ: Princeton University Press). Austin, J. (1954) The Province of Jurisprudence Determined (New York: Weidenfeld).

Copp, D. (2006) "On the Agency of Certain Collective Entities: An Argument from 'Normative Autonomy."' In P. French and H.K. Wettstein, eds., Midwest Studies in Philosophy: Shared Intentions and Collective Responsibility, vol. 30 (Boston: Blackwell). de Doelder, H. and K. Tiedemann, eds. (1996) Criminal Liability of Corporations (The Hague: Kluwer).

Dicey, A.V. (1959) An Introduction to the Law of the Constitution, 10th ed. (London: MacMillan 1959).

Dworkin, R. (2004) "Hart's Postscript and the Character of Political Philosophy." Oxford Journal of Legal Studies 24: 1-37.

Dyzenhaus, D. (1991) Hard Cases in Wicked Legal Systems: South African Law in the Perspective of Legal Philosophy (Oxford: Oxford University Press).

- (2005) "The State of Emergency in Legal Theory." In V.V. Ramraj, M. Hor, and K. Roach, eds., Global Anti-Terrorism Law and Policy, 65-89 (Cambridge, UK: Cambridge University Press).

. (2006) The Constitution of Law: Legality in a Time of Emergency (Cambridge, UK: Cambridge University Press).

— . (2007) "States of Emergency." In R.E. Goodin, P. Pettit, and T. Pogge, eds., A Companion to Contemporary Political Philosophy, 804-812 (Oxford: Oxford University Press). 
. (2008) "The Compulsion of Legality." In V.V. Ramraj, ed., Emergencies and the Limits of Legality, 33-59 (Cambridge, UK: Cambridge University Press).

. (2009) "The Puzzle of Martial Law." University of Toronto Law Journal 59: $1-64$.

—. (forthcoming 2010) "L'état d'exception." In M. Troper and D. Chagnollaud, eds., Traité international de droit constitutionnel (Paris: Dalloz).

Erskine, T. (2003) “Assigning Responsibilities to Institutional Moral Agents: The Case of States and 'Quasi-States." In T. Erskine, ed., Can Institutions Have Responsibilities: Collective Agency and International Relations, 19-40 (New York: Palgrave MacMillan).

Feinberg, J. (1965) “The Expressive Function of Punishment.” The Monist 49: 397423.

Finnis, J. (1973) "Revolutions and Continuity of Law." In A.W.B. Simpson, ed., Oxford Essays in Jurisprudence: Second Series, 44-76 (Oxford: Oxford University Press).

- (1980) Natural Law and Natural Rights (Oxford: Clarendon Press).

French, P. (1984) Collective and Corporate Responsibility (New York: Columbia University Press).

Fuller, L. (1967) Legal Fictions (Stanford, CA: Stanford University Press).

Gardner, J. (2008) "Hart and Feinberg on Responsibility.” In M.H. Kramer, C. Grant, B. Colburn, and A Hatzistavrou, eds., The Legacy of H.L.A. Hart: Legal, Political, and Moral Philosophy, 143-164 (Oxford: Oxford University Press).

Gee, G. and G.C.N. Webber. (2010) "What Is a Political Constitution?” Oxford Journal of Legal Studies 30: 1-27.

Green, L. (1990) The Authority of the State (Oxford: Oxford University Press).

Hart, H.L.A. (1968) Punishment and Responsibility: Essays in the Philosophy of Law (Oxford: Oxford University Press).

- (1982) Essays on Bentham: Jurisprudence and Political Theory (Oxford: Oxford University Press).

- (1994) The Concept of Law, 2nd ed. (Oxford: Clarendon Press).

Hobbes, Thomas (1996) Leviathan, edited by J.C.A. Gaskin (Oxford: Oxford University Press).

Jaconelli, J. (1999) “The Nature of Constitutional Convention.” Legal Studies 19: 24-46.

Kant, I. (1991) The Metaphysics of Morals, edited by Mary Gregor (Cambridge, UK: Cambridge University Press).

Kelsen, H. (1976) Pure Theory of Law, translated by Max Knight (Berkeley and Los Angeles: University of California Press).

— (1997) Introduction to the Problems of Legal Theory, translated by B. Litschewski Paulson and S.L. Paulson (Oxford: Oxford University Press).

. (2006) General Theory of Law and State (New Brunswick, NJ: Transaction Publishers).

List, C. and P. Pettit. (2008) "Group Agency and Supervenience." In J. Hohwy and J. Kallestrup, eds., Being Reduced: New Essays on Reduction, Explanation, and Causation, 75-92 (New York: Oxford University Press).

MacCormick, N. (1999) Questioning Sovereignty (Oxford: Oxford University Press).

McMahan, J. (2009) Killing in War (Oxford: Oxford University Press).

Nussbaum, M.C. (2007) The Clash Within: Democracy, Religious Violence, and India's Future (Cambridge, MA: Belknap Press).

Pettit, P. (2007) "Responsibility Incorporated.” Ethics 117: 171-201. 
Raz, J. (1979) The Authority of Law: Essays on Law and Morality (Oxford: Oxford University Press).

Press).

(1980) The Concept of a Legal System, 2nd ed. (Oxford: Oxford University

- (1990) Practical Reason and Norms, 2nd ed. (Oxford: Oxford University Press). . (2006) "The Problem of Authority: Revisiting the Service Conception." Minnesota Law Review 90: 1003-1044.

Ripstein, A. (2009) Force and Freedom: Kant's Legal and Political Philosophy (Cambridge, MA: Harvard University Press).

Schmitt, C. (2005) Political Theology: Four Chapters on the Concept of Sovereignty, translated by G. Schwab (Chicago: University of Chicago Press).

Tamir, Y. (1995) Liberal Nationalism (Princeton, NJ: Princeton University Press).

Thompson, D.F. (1985) “Criminal Responsibility in Government." In J.R. Pennock and J.W. Chapman, eds., Nomos XXVII: Criminal Justice, 201-240 (New York: New York University Press).

Thorburn, M. (2008) "Justifications, Powers, and Authority." Yale Law Journal 117: 1070-1130. 